\title{
Author Correction: Adaptive evolution of virulence and persistence in carbapenem-resistant Klebsiella pneumoniae
}

Christoph M. Ernst (D), Julian R. Braxton (D), Carlos A. Rodriguez-Osorio (D), Anna P. Zagieboylo, Li Li, Alejandro Pironti (D), Abigail L. Manson, Anil V. Nair, Maura Benson, Kaelyn Cummins, Anne E. Clatworthy, Ashlee M. Earl D, Lisa A. Cosimi and Deborah T. Hung (iD

Correction to: Nature Medicine https://doi.org/10.1038/s41591-020-0825-4, published online 13 April 2020.

In the version of this article initially published, the label ' $\Delta w c a$ ' ' was incorrect along the horizontal axis for Fig. 2e,f. The correct label is ' $\Delta w b a P$ '. In Extended Data Fig. 2 b, the fourth label (UCI_37 wbpA:IS $_{\text {) }}$ along the horizontal axis was incorrect. The correct label is 'UCI_37 ${ }_{w b a p: I S}$ '. In Extended Data Fig. 2m, the label 'UCI_38 $w$ waj' along the horizontal axis of each plot was incorrect. The correct label is 'UCI_38 $\Delta w b a P$ '. In Extended Data Fig. 4b, the third label (UCI_37_wcaJ::IS) along the horizontal axis was incorrect. The correct label is 'UCI_37_wbaP::IS'. The errors have been corrected in the HTML and PDF versions of the article.

Published online: 25 June 2020

https://doi.org/10.1038/s41591-020-0974-5

(C) The Author(s), under exclusive licence to Springer Nature America, Inc. 2020

\section{OPEN}

\section{Author Correction: A single-cell and single-nucleus RNA-Seq toolbox for fresh and frozen human tumors}

Michal Slyper, Caroline B. M. Porter, Orr Ashenberg, Julia Waldman, Eugene Drokhlyansky, Isaac Wakiro, Christopher Smillie, Gabriela Smith-Rosario, Jingyi Wu, Danielle Dionne, Sébastien Vigneau, Judit Jané-Valbuena, Timothy L. Tickle, Sara Napolitano, Mei-Ju Su, Anand G. Patel (D), Asa Karlstrom (1D, Simon Gritsch, Masashi Nomura (D), Avinash Waghray, Satyen H. Gohil, Alexander M. Tsankov, Livnat Jerby-Arnon, Ofir Cohen, Johanna Klughammer, Yanay Rosen, Joshua Gould (1), Lan Nguyen, Matan Hofree, Peter J. Tramontozzi@, Bo Li, Catherine J. Wu (D, Benjamin Izar, Rizwan Haq (iD, F. Stephen Hodi, Charles H. Yoon, Aaron N. Hata, Suzanne J. Baker, Mario L. Suvà (1D,

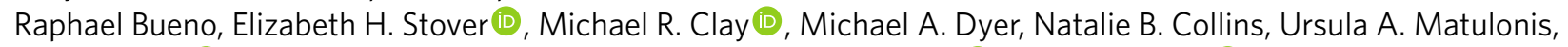
Nikhil Wagle (1D, Bruce E. Johnson, Asaf Rotem, Orit Rozenblatt-Rosen (10) and Aviv Regev (1)

Correction to: Nature Medicine https://doi.org/10.1038/s41591-020-0844-1, published online 11 May 2020.

In the version of this article initially published, two concentrations were incorrect (" $3 \mathrm{ml}$ of $100 \mu \mathrm{g} \mathrm{ml} \mathrm{l}^{-1}$ collagenase IV" and "final concentration of $1,250 \mu \mathrm{g} \mathrm{ml}^{-1}$ ") at the end of the final sentence of the Methods subsection 'NSCLC PDEC protocol'. The correct statement is as follows: “...3 ml of $100 \mathrm{mg} \mathrm{ml}{ }^{-1}$ collagenase IV (Thermo Fisher Scientific, cat. no. NC9836075) to a final concentration of $100 \mu \mathrm{g}$ $\mathrm{ml}^{-1}$." The error has been corrected in the HTML and PDF versions of the article.

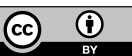

Open Access This article is licensed under a Creative Commons Attribution 4.0 International License, which permits use, sharing, adaptation, distribution and reproduction in any medium or format, as long as you give appropriate credit to the original author(s) and the source, provide a link to the Creative Commons license, and indicate if changes were made. The images or other third party material in this article are included in the article's Creative Commons license, unless indicated otherwise in a credit line to the material. If material is not included in the article's Creative Commons license and your intended use is not permitted by statutory regulation or exceeds the permitted use, you will need to obtain permission directly from the copyright holder. To view a copy of this license, visit http://creativecommons.org/licenses/by/4.0/.

Published online: 25 June 2020

https://doi.org/10.1038/s41591-020-0976-3

(C) The Author(s) 2020 